\title{
HUKUM IKUT BERJIHAD KE PALESTINA MEMBELA ISLAM
}

\author{
Muh. Yunan Putra, Lc., M. HI. \\ Institut Agama Islam (IAI) Muhammadiyah Bima \\ Jln. Anggrek No. 16 Ranggo Na'e Kota Bima \\ mohammed.elgehdy@gmail.com
}

\section{Abstrak}

Islam adalah agama yang membawa risalah perdamaian bukan hanya untuk orang Islam saja tapi bahkan kepada non-muslim, maka tidak heran Allah menyebutnya sebagai agama rahmatan lil alamin. Namun beberapa kelompok dan golongan menganggap Islam adalah agama yang ekstrim sehingga membuat kekacauan dan keributan serta peperangan dengan mengusung kata jihad. Adanya sebuah peperangan antara Islam dan kafir pada zaman Nabi dan para sahabat murni terjadi karena diawali dari pihak lawan, entah karena menyerang lebih dulu atau karena penghianatan dari para kaum kafir. Apa yang terjadi di India, Miyanmar, Surya, terutama yang terjadi di Negara Palestina saat ini. Serangan yang dilakukan Israel, tidak sedikit negera-negara Islam lain marah dan geram terhadap tindakan tersebut yang seakan tidak menganggap bahwa nyawa manusia tidak berharga sama sekali. Di Indonesiapun demikian, namun tidak ada yang bisa dilakukan selain berdo'a dan memberikan bantuan baik sandang, pangan dan papan untuk memenuhi kebutuhan saudara-saudara di Palestina dan tidak jarang diantara orang Islam di Indonesia berangkat ke Palestina dengan tujuan berjihad menegakkan panji Islam dalam upaya merebut kembali tanah Palestina.

Keyword: Berjihad, Palestina, Islam. 


\section{A. Pendahuluan}

Harus diakui bahwa sebenarnya tidak semua dari orangorang Yahudi buruk, diantara Yahudi terdapat pula manusia pilihan walaupun sedikit jumlahnya. Bahkan Allah memandang orang-orang tersebut sebagai kekasih-Nya dan mendapat petunjuk yang menyeru pada kemuliaan, kesalehan dan ketauhidan. Orang-orang tersebut tidak lain adalah para Nabi dan Rasul Allah, seperti Nabi Ya'qub As., Yusuf As., Musa As., Harun As., Daud As., Sulaiman As., Zakaria As., Yahya As. dan 'Isa As. Begitu juga dengan Thalut walaupun bukan Nabi dan Rasul, tetapi Allah memujinya karena semangat keagamaan dan jihadnya. ${ }^{1}$

Konflik Israil dan Palestina sebenarnya sudah lama terjadi, sejak akhir abad ke 19 sekitar tahun 1920 hingga 2020 saat ini dan tidak diketahui kapan berakhirnya. ${ }^{2}$ Ita Mutiara Dewi, Ajat Sudrajat dan Miftahuddin menyatakan bahwa terjadinya konflik antara Palestina dengan Israel adalah sejak masa Musa As. ${ }^{3}$ Dari rentetan konflik dengan berbagai macam jenis penyerangan yang dilakukan Negara Israil terhadap penduduk sipil Palestina yang meninggal dan kehilangan tempat tinggal. Warga Israil yang dulunya hanya sebagai tamu dan pendatang di wilayah palestina sekarang seakan telah menjadi tuan rumah dan menduduki sebagian besar wilayah, sementara orang

1 Mahir Ahmad Agha. 2005. Yahudi: Catatan Hitam Sejarah, terj. Yadi Indrayadi. Jakarta Timur: Qisthi Press. Hlm. 71-72. Lihat juga: Misri A. Muchsin. 2015. Palestina dan Israel: Sejarah, Konflik dan Masa Depan. Jurnal MIQOT Vol. XXXIX No. 2 Juli-Desember 2015. Hlm. 391.

2 Wikipedia bahasa Indonesia. 2020. Konflik Israel-Palestina. Diakses 20 Maret 2020. https://id.wikipedia.org/wiki/Konflik_Israel\%E2\%80\%93Palestina.

${ }^{3}$ Ita Mutiara Dewi, Ajat Sudrajat dan Miftahuddin. 2008. Gerakan Rakyat Palestina: Dari Deklarasi Negara Israel Sampai Terbentuknya Negara Palestina. Tidak diterbitkan. Fakultas Ilmu Sosial dan Ekonomi, Universitas Negeri Yogyakarta. Hlm. 6. 
Palestina sendiri seakan telah menjadi tamu tak diundang dirumah dan wilayah-wilayahnya.

Tindakan tersebut mengundang kecaman dari berbagai negara-negara yang tidak terima dan mengecam tindakan tersebut, terkhusus negara-negara Islam seperti Turki dan Indonesia. Maka tidak heran dengan segenap kemampuannya, Turki dibawah pimpinan Presiden Erdogan menantang dan memperingati Israil serta selalu siap melindungi Palestina. ${ }^{4}$ Tidak sampai disitu, Presiden Erdogan juga memperingati beberapa Negara Arab yang memberi dukungan terhadap Israil. ${ }^{5}$ Terlebih Palestina adalah sebuah kota suci bagi umat Islam, kota yang yang didalamnya terdapat Masjid Al Aqsa yang menjadi arah kiblat pertama bagi orang Islam, sebagaimana Allah berfirman:

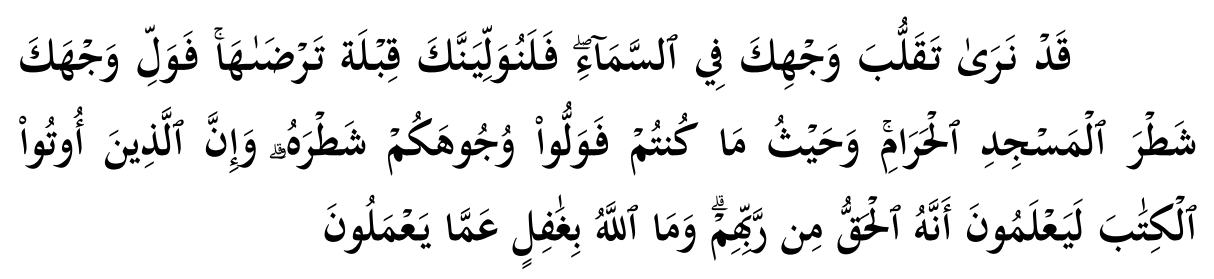

Terjemahnya:

"Sungguh Kami (sering) melihat mukamu menengadah ke langit, maka sungguh Kami akan memalingkan kamu ke kiblat yang kamu sukai. Palingkanlah mukamu ke arah Masjidil Haram. Dan dimana saja kamu berada, palingkanlah mukamu ke arahnya. Dan sesungguhnya orang-orang (Yahudi dan Nasrani) yang diberi Al Kitab (Taurat dan Injil) memang

${ }^{4}$ Willy Haryono. 2020. Erdogan Bertekad Lindungi Palestina dari Pencaplokan Israel. Diakses 26 Mei 2020. https://www.medcom.id/internasional/eropaamerika/ZkeBZp8K-erdogan-bertekad-lindungi-palestina-dari-pencaplokanisrael.

${ }_{5}$ Mahbub Ridhoo Maulaa. 2020. Usai Marah pada Uni Emirat Arab yang Dukung Israel, Presiden Erdogan Ancam dan Sebut Yunani 'Preman'. Diakses 16 Agustus 2020. https://www.pikiran-rakyat.com/internasional/pr-01670866/usaimarah-pada-uni-emirat-arab-yang-dukung-israel-presiden-erdogan-ancam-dansebut-yunani-preman.

Sangaji Jurnal Pemikiran Syariah dan Hukum 
mengetahui, bahwa berpaling ke Masjidil Haram itu adalah benar dari Tuhannya; dan Allah sekali-kali tidak lengah dari apa yang mereka kerjakan." (QS. Al baqarah: 144)

Palestina juga menjadi tempat singgah Rasulullah ketika melakukan Isra' dan Mi'raj sebelum menuju ke sidratul muntaha. Sebagaimana dalam firman-Nya:

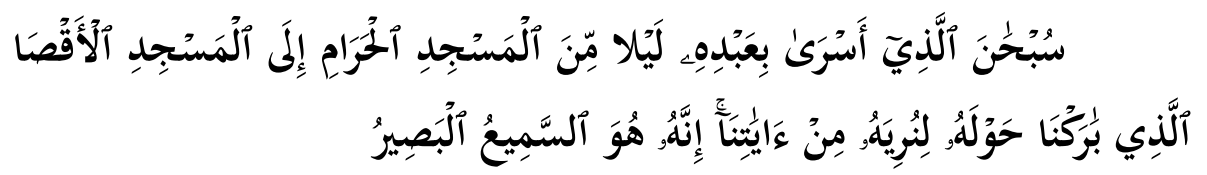

Terjemahnya:

"Maha Suci Allah, yang telah memperjalankan hamba-Nya pada suatu malam dari Al Masjidil Haram ke Al Masjidil Aqsha yang telah Kami berkahi sekelilingnya agar Kami perlihatkan kepadanya sebagian dari tandatanda (kebesaran) Kami. Sesungguhnya Dia adalah Maha Mendengar lagi Maha Mengetahui." (QS. Al Isra': 1)

Demikian dengan Indonesia, dengan penduduk mayoritas Islamnya mengecam keras terhadap tindakan dan serangan Israil terhadap Palestina. Walaupun tidak bisa melakukan seperti yang dilakukan Presiden Erdogan, setidaknya penduduk Indonesia telah banyak membantu dan ikut berpartisipasi dalam menolong atau serendah-rendahnya mendo'akan saudara seiman dan seakidahnya di Palestina. Dan sebagian lain bahkan membuat sebuah organisasi atau kelompok untuk turut serta berjuang bersama ke Palestina. Lalu bagaimana sebenarnya hukum bagi orang Islam di Indonesia atau negara lain yang berangkat ke Palestina untuk berjuang bersama? Apakah bagi mereka yang dianggap sebenarnya mampu dan memiliki kelebihan berdosa dihadapan Allah apabila tidak membantu dan berjuang bersama saudara di Palestina? Inilah yang dicoba oleh penulis untuk dikupas, dengan harapan memberikan sedikit manfaat bagi penulis sendiri dan yang membaca tulisan singkat ini. 


\section{B. Pengertian}

\section{Jihad}

Lafal jihad berasal dari kata dasar jahd yang artinya usaha, jerih payah, dan kesukaran. Kata jahada-yujahidumujahadah-jihad artinya berusaha sungguh-sungguh dengan mencurahkan jerih payah dalam rangka melaksanakan perintah Allah; berjuang. Ayat-ayat jihad dalam konteks perjuangan berjumlah 28, empat ayat turun pada periode Makkah dan selebihnya periode Madinah. ${ }^{6}$ Dari ayat-ayat tersebut itu dapat dirumuskan bahwa jihad adalah perjuangan orang beriman dengan mencurahkan kemampuan moril dan materil berupa tenaga, pikiran maupun harta benda untuk menegakkan agama Allah dan meninggikan kalimat-Nya. ${ }^{7}$

Jihad juga bermakna kesungguhan dan upaya terakhir, sebagaimana dalam firman Allah: "Dan mereka bersumpah dengan nama Allah dengan segala kesungguhan." (QS. Al An'am: 509). Makna kata al-jahdu dan al-jihād menurut kitab lisānul'Arab yang ditulis oleh Ibnu Mandzur ialah melawan musuh, pengerahan segenap kemampuan manusia untuk mendapatkan yang diinginkan atau menolak yang dibenci. Sedang dalam kamus al-Munawwir yang ditulis oleh Ahmad Warson Munawwir memberikan suatu pengertian bahwa lafal jihad sebagai suatu kegiatan yang mencurahkan

${ }^{6}$ Ayat-ayat jihad periode Makkah yang dimaksud secara berurutan adalah QS. al Furqan (25): 52, QS. al Nahl (16): 110, QS. al Ankabut (29): 6, QS. al Ankabut (29): 69. Periode Madinah; Al Baqarah [2]: 218, Al Anfal [8]: 72, 74, 75, Ali 'Imran [3]: 142, Al Mumtahanah [60]: 1, Al Nisa' [4]: 95, Muhammad [47]: 31, Al Hajj [22]: 78, Al Hujurat [49]: 15, Al Tahrim [66]: 9, Al Saff [61]: 11, Al Ma'idah [5]: 35, 54, dan Al Taubah [9]: 16, 19, 20, 24, 41, 44, 73, 81, 86, 88.

${ }^{7}$ Muhammad Chirzin. 2006. Reaktualisasi Jihad fî Sabîl al-Lâh dalam Konteks Kekinian dan Keindonesiaan. Jurnal Ulumuna, Volume X Nomor 1 Januari-Juni 2006. Hlm. 60. Lihat juga: Muhammad Fu'ad Abd al Baqi. 1991. Al Mu'jam al Mufahras li Alfazh al Qur'an al Karim (Kairo: Dar al Hadits. Hlm. 232.

Sangaji Jurnal Pemikiran Syariah dan Hukum 
segala kemampuan. Apabila dirangkaikan dengan lafal fī sabīlillāh, maka diartikan sebagai berjuang, berjihad, berperang dijalan Allah.

Jihad juga bermakna kesungguhan dan upaya terakhir, sebagaimana dalam firman Allah: "Dan mereka bersumpah dengan nama Allah dengan segala kesungguhan." (QS. Al An'am: 109). Makna kata al jahdu menurut kamus Lisanul Arab yang ditulis oleh Ibnu Mandzur ${ }^{8}$ adalah melawan musuh, pengerahan segenap kemampuan manusia untuk mendapatkan yang diinginkan atau menolak yang dibenci. Sedang dalam kamus al munawwir yang ditulis oleh Ahmad Warson Munawwir ${ }^{9}$ memberikan suatu pengertian bahwa lafal jihad sebagai suatu kegiatan yang mencurahkan segala kemampuan. Apabila dirangkaikan dengan lafal fi sabilillah, maka diartikan sebagai berjuang, berjihad, berperang dijalan Allah.

Dilihat dari istilah syara', para fuqaha dari empat madzhab telah mendefinisikan bahwa makna jihad adalah mengerahkan kemampuan dengan sungguh-sungguh melalui harta dan jiwa dalam menegakkan agama Allah dan mempertahankannya sesuai dengan aturan hukum syara' yang berlaku. Dibawah ini akan diuraikan pengertian jihad yang dikemukakan oleh para fuqaha keempat madżhab itu. Sebagaimana yang ditulis oleh Shaheed Abdullah Azzam yang diterjemahkan oleh Mahmud Malawi, dalam kitabnya Jihad Adab dan Hukumnya, sebagai berikut: ${ }^{10}$

${ }^{8}$ Lihat: Ibnu Mandzur. Lisan al Arab al Muhit Juz I. Beirut: Dar Lisan al Arab. Hlm. 521.

9 Lihat: Ahmad Warson Munawwir. 1984. Al Munawwir: Kamus Arab Indonesia. Yogyakarta: Pondok Pesantren al Munawwir. Hlm. 234

10 Agus Handoko. 2014. Konsep Jihad Dalam Perspektif Alquran (Studi Tematik Dalam Tafsir al-Kasysyaf Atas Ayat-Ayat Jihad). Mizan: Jurnal Ilmu Syariah. Volume 2 No. 2 Desember 2014. Hlm. 190-191. 
a) Hanafi. Al Kasani mengatakan dalam kitabnya al Bada'i, juz 9/4299 bahwa al jihad berarti mengerahkan segenap kemampuan dan tenaga dengan melakukan perlawanan dan pertahanan dari ancaman musuh (kafir harbi), baik dengan diri, harta, maupun lisannya.

b) Maliki. Makna jihad diperuntukkan kepada orang-orang muslim dengan melawan orang-orang kafir harbi yang tidak terikat dalam perjanjian (damai) demi menegakkan ajaran Allah SWT.

c) Syafi'ie. Al Baijuri mengatakan al jihad adalah melawan musuh dari ancaman dan serangan bertujuan jihad di jalan Allah. Selain itu, Ibnu Hajar dalam Fathul Bari, juz 2/6 juga mengatakan bahwa ditinjau dari hukum syara', jihad berarti mengerahkan segenap kemampuan untuk melawan orang kafir harbi.

d) Hambali. Jihad artinya melawan orang-orang kafir harbi. Jihad juga berarti melawan musuh dan mengerahkan segenap kemampuan untuk menegakkan kalimat Allah.

\section{Palestina}

Negara Palestina (bahasa Arab: دولة فلسطين), Dawlat Filastin, atau hanya Palestina (bahasa Arab: فلسطين, Filastin) adalah sebuah negara di Timur Tengah antara Laut Tengah dan Sungai Yordan. Status politiknya masih dalam perdebatan. Sebagian besar Negara di dunia termasuk Negara-negara anggota OKI, Liga Arab, Gerakan Non-Blok, dan ASEAN telah mengakui keberadaan Negara Palestina. ${ }^{11}$

Bangsa Palestina atau orang Palestina adalah orangorang Arab dari Tepi Barat dan Jalur Gaza, yang juga disebut Wilayah Palestina. Orang-orang yang disebut "Palestina" hari ini adalah orang Arab, tetapi pada masa lalu,

11 Wikipedia Indonesia. 2020. Negara Palestina. Diakses 25 Juli 2020. https://id.wikipedia.org/wiki/Negara_Palestina

Sangaji Jurnal Pemikiran Syariah dan Hukum 
"Palestina" juga dapat digunakan sebagai nama bagi orangorang Yahudi yang tinggal di Palestina.

Bangsa Palestina (bahasa Arab:الثعب الفلسطيني, ash-sha'b al filastīni) adalah bangsa yang menuturkan bahasa Arab. Populasi Bangsa Palestina, termasuk keturunan, jika dibulatkan adalah 10 juta jiwa, kira-kira setengah tinggal di wilayah Palestina, mencakup wilayah Israel, Tepi Barat termasuk Yerusalem Timur, Jalur Gaza dan Yordania. Di daerah ini jika digabungkan pada 2009, mereka merupakan mayoritas 51\% dari seluruh penduduk. Beberapa di antaranya adalah pengungsi. Sisanya, lebih dari separuh dari seluruh Palestina terdiri dari yang dikenal sebagai diaspora Palestina, yang kebanyakan adalah pengungsi Palestina di negara manapun. Dari diaspora, lebih dari dua setengah juta hidup di negara tetangga Yordania, satu juta dibagi antara Suriah dan Lebanon, seperempat juta di Arab Saudi, dan Chile setengah juta adalah konsentrasi terbesar di luar dunia Arab. ${ }^{12}$

\section{Berjihad di Jalan Allah (Fi Sabilillah)}

Seruan jihad adalah salah satu isu yang sangat sensitif dan banyak dibicarakan saat ini, hal tersebut terjadi karena setiap kali kata jihad disebutkan maka selalu dikaitkan dengan terorisme. Bahkan jihad (fisabillah) menjadi bahan perdebatan dalam media massa dan buku-buku akademis, baik di Timur maupun di Barat. Oleh sebab itu jihad merupakan salah satu ajaran Islam yang paling sering disalah pahami bahkan oleh orang Islam sendiri dan seringkali disebut sebagai penyebab munculnya berbagai macam kekerasan. Maka sebagai seorang muslim yang tahu, berpengahuan, berpendidikan dan taat tentunya sangat tidak sepakat dan menolak terhadap

12 Wikipedia Indonesia. 2020. Bangsa Palestina. Diakses 16 Agustus 2020. https://id.wikipedia.org/wiki/Bangsa_Palestina 
pernyataan miring tentang arti jihad yang dipahami sebagai tindakan kekerasan (terorisme). Karena sangat jelas garis pemisah antara keduanya. ${ }^{13}$

Iman Santoso menyebutkan bahwa dalam Al Quran, penggunaan kata jihad dapat dikelompokkan ke dalam beberapa bagian: ${ }^{14}$

a) Jihad melawan orang kafir dengan menggunakan argument dan hujjah, Allah berfirman.

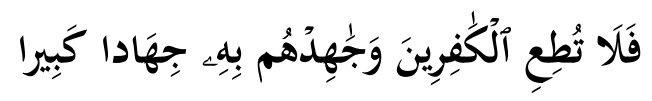

Terjemahnya:

"Maka janganlah kamu mengikuti orang-orang kafir, dan berjihadlah terhadap mereka dengan Al Quran dengan jihad yang besar." (QS. Al Furqan [25]: 52)

b) Jihad melawan pendukung kesesatan dengan harta dan jiwa, Allah berfirman.
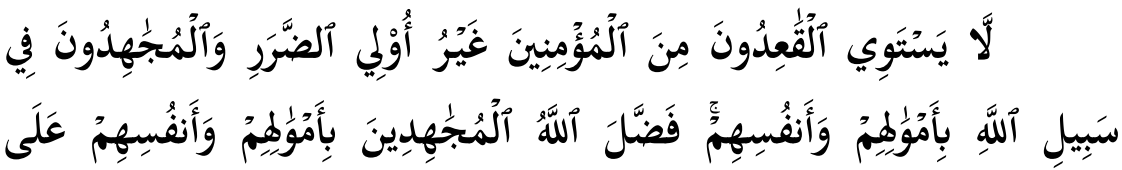

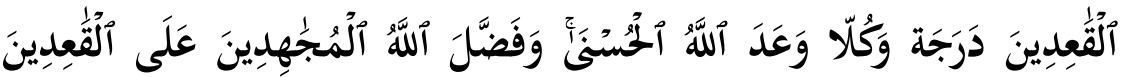
أَجُرًا عَظِيما

Terjemahnya:

"Tidaklah sama antara mukmin yang duduk (yang tidak ikut berperang) yang tidak mempunyai 'uzur dengan orang-orang yang berjihad di jalan Allah dengan harta mereka dan jiwanya.

${ }^{13}$ Musda Asmara. 2016. Reinterpretasi Makna Jihad dan Teroris. Al Istinbath: Jurnal Hukum Islam STAIN Curup-Bengkulu Volume 1 Nomor 1 2016. Hlm. 64.

14 Abdul Jalal dan Abdul Aziz. 2017. Pondok Pesantren Dan Jihad: Studi Tentang Pembelajaran Konsep Jihad Di Pondok Pesantren Nurussalam Ciamis. Jurnal Penelitian Pendidikan Islam. Volume 5 Nomor 1 2017. Hlm. 60. Lihat juga: Imam Santosa. 2008. Nasihat Untuk Qiyadah dan Kader Dakwah. Jakarta :Robbani Press.

Sangaji Jurnal Pemikiran Syariah dan Hukum 
Allah melebihkan orang-orang yang berjihad dengan harta dan jiwanya atas orang-orang yang duduk satu derajat. Kepada masing-masing mereka Allah menjanjikan pahala yang baik (surga) dan Allah melebihkan orang-orang yang berjihad atas orang yang duduk dengan pahala yang besar." (QS. Al Nisa [4]: 95)

c) Jihad melawan hawa nafsu, Allah berfirman.

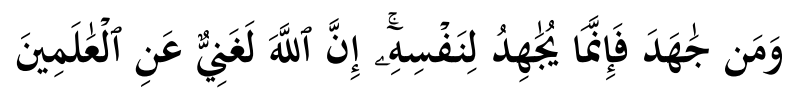

Terjemahnya:

"Dan barangsiapa yang berjihad, maka sesungguhnya jihadnya itu adalah untuk dirinya sendiri. Sesungguhnya Allah benar-benar Maha Kaya (tidak memerlukan sesuatu) dari semesta alam." (QS. Al Ankabut [29]: 6)

d) Jihad melawan syetan dengan cara tidak mentaatinya karena mengharapkan hidayah dari Allah. Allah berfirman.

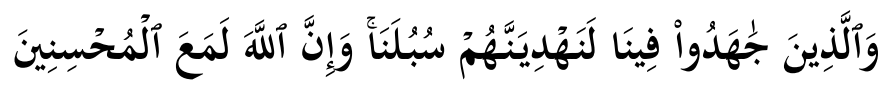

Terjemahnya:

"Dan orang-orang yang berjihad untuk (mencari keridhaan) Kami, benar-benar akan Kami tunjukkan kepada mereka jalan-jalan Kami. Dan sesungguhnya Allah benar-benar beserta orang-orang yang berbuat baik." (QS. Al Ankabut [29]: 69)

e) Jihad melawan kezaliman. Allah berfirman.

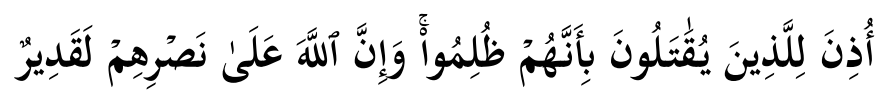

Terjemahnya:

"Telah diizinkan (berperang) bagi orang-orang yang diperangi, karena sesungguhnya mereka telah dianiaya. Dan sesungguhnya Allah, benar-benar Maha Kuasa menolong mereka itu." (QS. Al Hajj [22]: 39) 
Hal serupa juga diungkapkan oleh Quraish Shihab ketika mengutip pendapat Al-Raghib dalam kamus al-Qur'an " $M u^{\prime} j a m$ Mufradat al Fazh al Qur'an", yang menyebutkan bahwa jihad dan mujahadah adalah mengerahkan segala tenaga untuk mengalahkan musuh yang terdiri dari tiga macam: ${ }^{15}$

a) Jihad al nafs (jihad dalam memperbaiki diri sendiri). Maksudnya adalah mencurahkan segenap usaha dan kemampuan untuk berkomitmen terhadap aturan Allah SWT dan meniti jalan-Nya yang lurus. Hal ini mecakup ketaatan dan peribadahan kepada Allah SWT, menjauhi maksiat, dengan melaksanakan kewajiban terhadap Tuhan, diri, umat, semua manusia, alam, dan semua makluk. ${ }^{16}$

b) Jihad al syaitan (jihad melawan setan), Menurut Imam al Ghazali dalam kitabnya "Ihya Ulumuddin" sejumlah pintu masuk setan dan tempat-tempat masuk lainnya ke dalam hati manusia. Diantara pintu-pintunya yang besar adalah amarah dan syahwat, hasut dan iri hati, makan berlebihan, cinta dalam menghias perabot rumah, pakaian dan rumah (berlebih-lebihan), tamak terhadap manusia, tergesa-gesa dan tidak berhati-hati dalam segala hal, kikir dan takut fakir, fanatik terhadap madzab dan hawa nafsu, dendam terhadap musuh dan memandang rendah dan melecehkan mereka, membawa masuk orang awam ke dalam ilmu yang tidak membuat baik, buruk sangka terhadap kaum muslim, dan yang lainnya. ${ }^{17}$

15 Abdul Jalal dan Abdul Aziz. 2017. Pondok Pesantren Dan Jihad: Studi Tentang Pembelajaran Konsep Jihad Di Pondok Pesantren Nurussalam Ciamis. Jurnal Penelitian Pendidikan Islam. Volume 5 Nomor 1 2017. Hlm. 60.

16 Slamet Pramono dan Saifullah. 2015. Pandangan Hamka Tentang Konsep Jihad Dalam Tafsir Al-Azhar. Dialogia, Jurnal Studi Islam dan Sosial Volume 13 Nomor 2 2015. Hlm. 115. Lihat juga: Dzulqarnain M. Sunusi.2011. Antara Jihad dan Terorisme. Makassar: Pustaka As-Sunnah. Hlm. 53.

17 Slamet Pramono dan Saifullah. 2015. Pandangan Hamka Tentang Konsep Jihad Dalam Tafsir Al-Azhar. Dialogia, Jurnal Studi Islam dan Sosial Volume 13 
c) Jihad al kuffar wa al munafiqin (jihad melawan orang-orang kafir dan kaum munafikin), Jihad melawan orang-orang kafir termasuk jihad yang paling banyak disebutkan dalam nash-nash al-Quran dan al-sunnah. Adapun jihad menghadapi kaum munafikin ditempuh dengan empat tingkatan: ${ }^{18}$

1) Memerangi mereka dengan menanamkan kebencian didalam hati terhadap perilaku, kesewenang-wenangan, dan sikap mereka yang menodai kemuliaan syariat Allah Swt.

2) Memerangi mereka dengan lisan dalam bentuk menjelaskan kesesatan mereka dan menjauhkan mereka dari kaum muslimin.

3) Memerangi mereka dengan menginfakkan harta dalam mendukung berbagai kegiatan untuk mematahkan segala makar jahat dan permusuhan mereka terhadap Islam dan kaum muslimin.

4) Memerangi mereka dalam arti yang sebenarnya, yaitu dengan membunuh mereka kalau terpenuhi syaratsyarat yang disebutkan oleh para ulama dalam perkara tersebut.

Menurut Al Isfihani ketiga hal tentang pembagian jihad tersebut telah dimuat dalam Firman Allah.

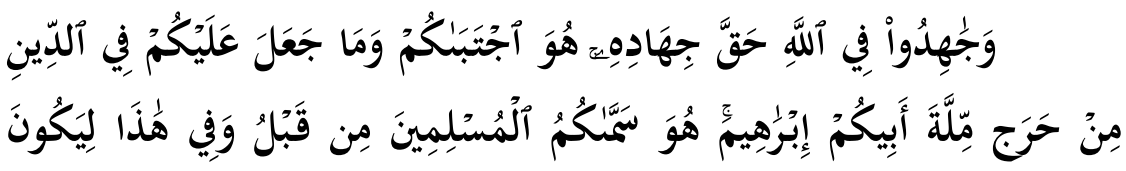

Nomor 2 2015. Hlm. 115. Lihat juga: Qardhawi. 2010. Fiqih al Jihad, Terj. Irfan Maulana, dkk. Bandung: PT. Mizan Pustaka. Hlm. 5.

18 Slamet Pramono dan Saifullah. 2015. Pandangan Hamka Tentang Konsep Jihad Dalam Tafsir Al-Azhar. Dialogia, Jurnal Studi Islam dan Sosial Volume 13 Nomor 2 2015. Hlm. 115. Lihat juga: Dzulqarnain M. Sunusi.2011. Antara Jihad dan Terorisme. Makassar: Pustaka As-Sunnah. Hlm. 71-72. 


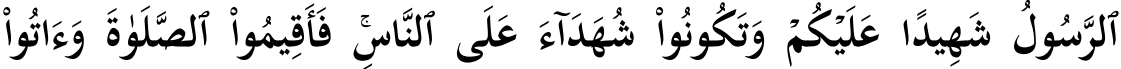

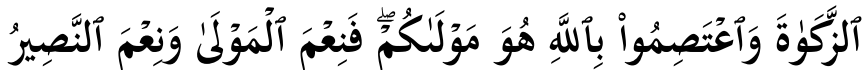

Terjemahnya:

"Dan berjihadlah kamu pada jalan Allah dengan jihad yang sebenar-benarnya. Dia telah memilih kamu dan Dia sekali-kali tidak menjadikan untuk kamu dalam agama suatu kesempitan. (Ikutilah) agama orang tuamu Ibrahim. Dia (Allah) telah menamai kamu sekalian orang-orang muslim dari dahulu, dan (begitu pula) dalam (Al Quran) ini, supaya Rasul itu menjadi saksi atas dirimu dan supaya kamu semua menjadi saksi atas segenap manusia, maka dirikanlah sembahyang, tunaikanlah zakat dan berpeganglah kamu pada tali Allah. Dia adalah Pelindungmu, maka Dialah sebaik-baik Pelindung dan sebaik-baik Penolong." (QS. Al Hajj [22]: 78)

\section{Hukum Berjihad ke Palestina}

Pada penjelasan sebelumnya telah diungkapkan tentang beberapa pengelompokan jihad oleh para ulama yang para ulama tersebut menyimpulkannya dari Al-Quran maupun hadits-hadits Rasulullah tentang jihad. Pada tulisan ini penulis tidak membahas hal tersebut satu persatu secara datailnya, namun hanya mengambil satu point inti jihad melawan kezhaliman sebagaimana yang diungkapkan oleh Imam Santoso atau jihad melawan orang-orang kafir dan kaum munafikin sebagaimana yang diungkapkan oleh Quraish Shihab.

Kezhaliman Israil terhadap muslim Palestina telah meluluh lantahkan negeri yang menjadi arah kiblat pertama kaum muslimin. Puluhan bahkan ratusan bangunan hancur dan rata dengan tanah, manusia yang menjadi korban jiwa sudah tidak terhitung jumlahnya. Hingga saat ini bom terus berjatuhan sedang korban terus bertambah, bahkan yang lebih menyakitkan adalah tidak diketahui sampai kapan hal ini akan terus berlangsung.

Sangaji Jurnal Pemikiran Syariah dan Hukum 
Atas dasar hal tersebut, beberapa orang yang merasa terketuk hatinya bangkit dan mengambil sebuah inisiatif untuk berangkat dan berjuang bersama saudara-saudaranya di Palestina, baik itu dari negeri sekitar palestina sendiri (timur tengah) atau bahkan tidak jarang orang Indonesia ikut berpartisipasi.

Kalau berpedoman pada ayat dan hadits, terutama yang telah disebutkan di atas tentang perintah Allah untuk memerangi kaum musyrik yang telah menzhalimi orang Islam, maka perbuatan tersebut adalah sesuatu yang sangat wajar dan dianggap sebagai jihad fi sabilillah, dan tentunya bagi yang mati dalam keadaan berperang adalah syahid yang telah dijanjikan oleh Allah surga bagi mereka, sebagaimana firman Allah Swt.

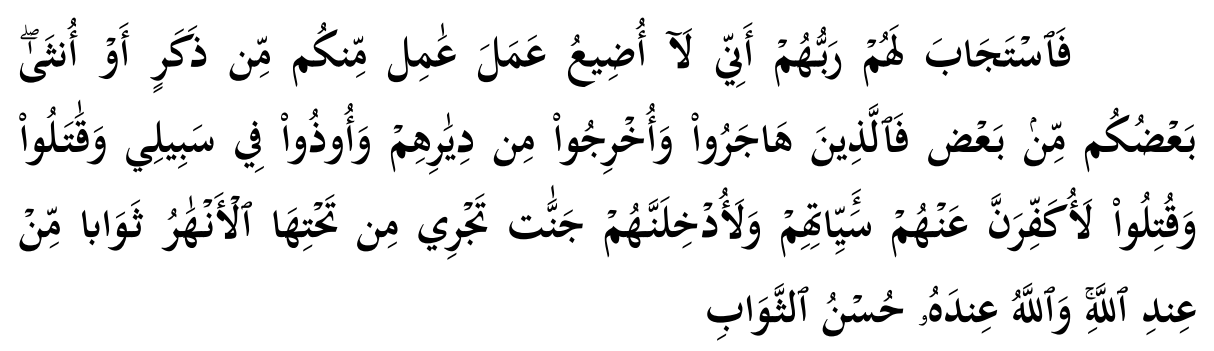

Terjemahnya:

"Maka Tuhan mereka memperkenankan permohonannya (dengan berfirman): "Sesungguhnya Aku tidak menyia-nyiakan amal orang-orang yang beramal di antara kamu, baik laki-laki atau perempuan, (karena) sebagian kamu adalah turunan dari sebagian yang lain. Maka orang-orang yang berhijrah, yang diusir dari kampung halamannya, yang disakiti pada jalan-Ku, yang berperang dan yang dibunuh, pastilah akan Ku-hapuskan kesalahan-kesalahan mereka dan pastilah Aku masukkan mereka ke dalam surga yang mengalir sungai-sungai di bawahnya, sebagai pahala di sisi Allah. Dan Allah pada sisi-Nya pahala yang baik"." (QS. Al Imran: 195)

Tidak hanya itu, hikmah lain yang diperoleh bagi yang berangkat dan mati di medan jihad adalah bahwa mereka 
dihadapan dan menurut pandangan Allah tetap hidup dan harum namanya, Allah berfiman:

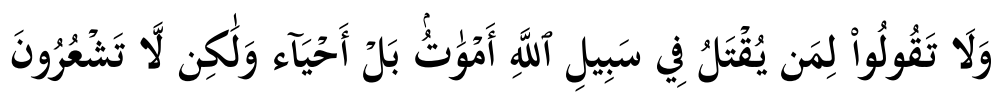

Terjemahnya:

"Dan janganlah kamu mengatakan terhadap orang-orang yang gugur di jalan Allah, (bahwa mereka itu) mati; bahkan (sebenarnya) mereka itu hidup, tetapi kamu tidak menyadarinya." (QS. Al Baqarah: 154)

Hal lain yang yang diperoleh adalah bahwa mereka yang gugur dalam keadaan gembira oleh luasnya karunia Allah yang didapatkan.

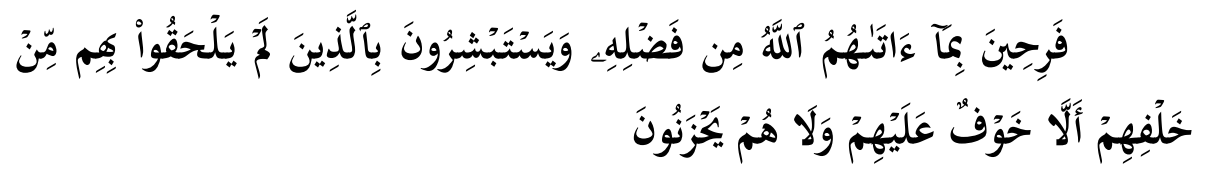

Terjemahnya:

"Mereka dalam keadaan gembira disebabkan karunia Allah yang diberikan-Nya kepada mereka, dan mereka bergirang hati terhadap orangorang yang masih tinggal di belakang yang belum menyusul mereka, bahwa tidak ada kekhawatiran terhadap mereka dan tidak (pula) mereka bersedih hati." (QS. Al Imran: 170)

Dan masih banyak lagi hikmah dan kelebihan lain yang Allah janjikan bagi para syahid di jalan-Nya. Namun apabila dikaji kembali tentang keberangkatan beberapa saudara muslim ke Palestina, ditemukan beberapa catatan kecil yang perlu digaris bawahi, diantaranya:

\section{Mendapat izin dari orang tua}

Izin dari orang tua kandung yang masih hidup adalah sesuatu yang sangat diwajibkan sebelum berangkat berjihad, yang apabila orang tua melarang maka tidak dibolehkan untuk berangkat, hal sebagaimana dalam hadits riwayat Bukhari dan Muslim:

Sangaji Jurnal Pemikiran Syariah dan Hukum 
"Seseorang telah datang kepada Rasulullah SAW untuk meminta izin berangkat jihad. Maka beliau SAW bertanya," Adakah kamu masih punya kedua orang tua?". Dia menjawab,"Ya, masih". Rasulullah SAW berkata,"Berjihadlah pada keduanya".

Lalu bagaimana kalau seandainya orang tua masih dalam keadaan kafir atau musyrik, apakah perlu mendapat izin darinya? Diantara para sahabat yang sering ikut berjihad namun orang tuanya masih belum beragama Islam adalah Abu Bakar Al-Shiddiq dan Abu Hudzaifah bin Utbah. Abu Quhafah adalah ayahanda dari Abu Bakar AlShiddiq dan Utbah bin Rabi'ah adalah ayahanda dari Abu Hudzaifah, keduanya masih kafir ketika anak-anak mereka ikut berjihad di jalan Allah.

Artinya, kalau orang tua masih dalam keadaan kafir atau musyrik maka tidak diperlukan untuk mendapat izin darinya, sebagaimana yang terjadi pada dua sahabat di atas.

\section{Izin dari ulil amri}

Tidak hanya mendapat izin dari orang tua, izin dari ulil amri adalah merupakan syarat mutlak untuk dapat pergi berjihad, hal ini sebagaimana dalam firman Allah yang memerintahkan untuk senantiasa taat kepada-Nya, Rasul dan ulil amri.

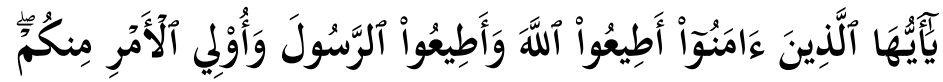

Terjemahnya:

"Hai orang-orang yang beriman, taatilah Allah dan taatilah Rasul (Nya), dan ulil amri di antara kamu." (QS. Al nisa 59)

Yang termasuk ulil amri adalah yang mengatur urusan kenegeraan, kemaslahatan dan yang menyatakan adanya keadaan darurat. Mereka yang mengatur demikian 
sesuai dengan kewenangan yang berlaku. Kewajiban sebagai muslim adalah tetap bersama jama'ah kaum muslimin. Tetap taat pada kedua orang tua dan tetap taat di bawah ulil amri. Tidak mengapa jika hanya mendo'akan kaum muslimin di mana saja berada, di Irak, Palestina maupun tempat lainnya.

Dua syarat tersebut di atas adalah sebagaimana yang diungkapkan oleh Syaikh Shaleh Al Fauzan ketika beliau ditanya terkait keberangkatan para kaum muslim untuk berjihad di Irak. ${ }^{19}$

\section{Kemampuan Finansial ${ }^{20}$}

Syarat lain yang harus dipenuhi oleh orang yang akan berjihad adalah kemampuan dalam hal finansial, karena jangan sampai keberangkatan tersebut malah akan menyusahkan orang yang ditinggalkan atau orang lain yang berangkat bersama dengannya. Oleh karena itu jihad adalah ibadah yang multi dimensi, bukan hanya terkait dengan fisik tetapi termasuk menuntut harta bahkan jiwa. Orang yang berjihad di jalan Allah Swt. maka harus memenuhi syarat kemampuan, yang rinciannya antara lain:

a) Nafkah

Yang dimaksud dengan nafkah disini bukan hanya untuk dirinya, tetapi juga untuk keluarga yang ditinggalkan. Sebab meskipun pergi berjihad, tetapi seorang suami tetap wajib memberi nafkah kepada istrinya. Seorang Ayah tetap wajib memberi nafkah kepada anak-anaknya. Kewajiban memberi nafkah tidak gugur dengan alasan pergi berjihad. Dan bila belum ada

19 Muhammad Abduh Tuasikal. 2011. Dua Syarat Pergi Jihad. Diakses 21 januari 2011. https://rumaysho.com/1528-dua-syarat-pergi-jihad.html

20 Acheh Cyber Military. 2017. Syarat-Syarat Untuk Mengikuti Jihad Fisabilillah. Diakses 3 Januari 2017. http://achehcybermilitary.org/syarat-syaratuntuk-mengikuti-jihad-fisabilillah.

Sangaji Jurnal Pemikiran Syariah dan Hukum 
pihak yang menjamin keberlangsungan nafkah buat anak dan istri, seorang laki-laki tidak wajib berangkat untuk berjihad.

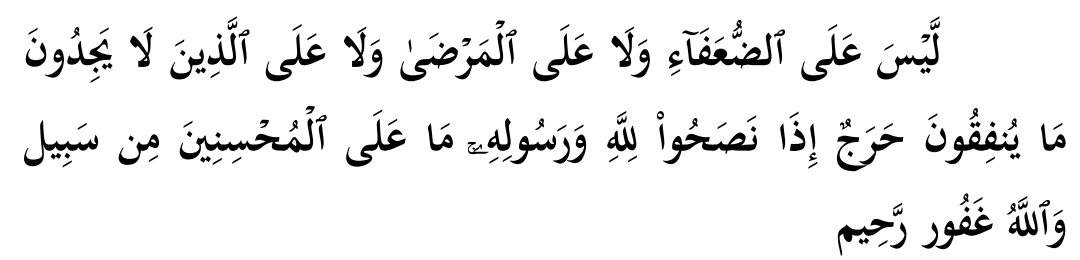

Terjemahnya:

"Tiada dosa (lantaran tidak pergi berjihad) atas orangorang yang lemah, orang-orang yang sakit dan atas orangorang yang tidak memperoleh apa yang akan mereka nafkahkan, apabila mereka berlaku ikhlas kepada Allah dan Rasul-Nya. Tidak ada jalan sedikitpun untuk menyalahkan orang-orang yang berbuat baik. Dan Allah Maha Pengampun lagi Maha Penyayang." (QS. Al Taubah: 91)

b) Biaya Perjalanan

Selanjutnya adalah biaya perjalanan, karena jauhnya tempat berjihad tidak menjadi tanggungan orang lain dan tidak juga boleh meminta orang lain untuk menanggungnya sehingga menyusahkan. Allah berfirman:

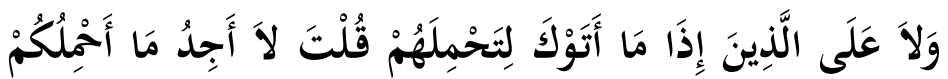

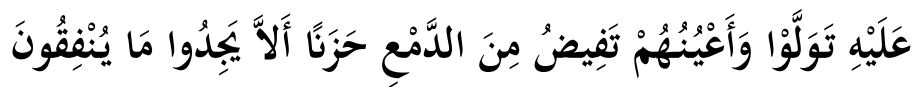

Terjemahnya:

"Dan tiada berdosa atas orang-orang yang apabila mereka datang kepadamu, supaya kamu memberi mereka kendaraan, lalu kamu berkata: "Aku tidak memperoleh kendaraan untuk membawamu." Lalu mereka kembali, sedang mata mereka bercucuran air mata karena kesedihan, lantaran 
mereka tidak memperoleh apa yang akan mereka nafkahkan." (QS. Al Taubah: 92)

Banyak para sahabat Nabi Saw. yang pulang menangis bercucuran air mata, karena hasrat hati ingin ikut berjihad fi sabilillah, namun apa daya ternyata tidak punya harta untuk membiayai perjalanan jauh, maka dengan terpaksa Rasulullah Saw. menolak mereka ikut.

c) Senjata dan Perlengkapan

Dan yang terakhir adalah senjata dan perlengkapan lain yang perlu untuk untuk dipersiapkan sehingga dengannya para mujahid akan menghadapi musuh. Tidak ada perang tanpa senjata, sebab jihad bukan adu tinju dengan tangan kosong. Jihad adalah pertempuran, dimana sejarah peperangan di muka bumi selalu identik dengan adu persenjataan, meski senjata bukan satu-satunya faktor kemenangan.

Allah Swt. mensyariatkan jihad kepada umat Islam yang mampu mengadakan senjata untuk dirinya, baik dengan cara membuatnya atau membelinya. Dan senjata termasuk barang mahal yang tidak semua orang mampu untuk memilikinya.

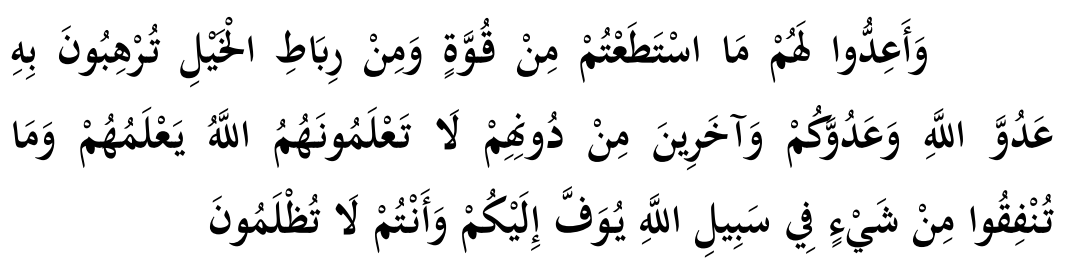

Terjemahnya:

"Dan siapkanlah untuk menghadapi mereka kekuatan apa saja yang kamu sanggupi dan dari kuda-kuda yang ditambat untuk berperang kamu menggentarkan musuh Allah dan musuhmu dan orang orang selain mereka yang kamu tidak mengetahuinya; sedang Allah mengetahuinya. Apa saja

Sangaji Jurnal Pemikiran Syariah dan Hukum 
yang kamu nafkahkan pada jalan Allah niscaya akan dibalasi dengan cukup kepadamu dan kamu tidak akan dianiaya." (QS. Al Anfal: 60)

\section{Kekuatan Jasad dan Kesehatan ${ }^{21}$}

Jihad adalah perang dan perang adalah mengadu kekuatan fisik. Oleh sebab itu hanya orang yang jasadnya kuat dan sehat yang diizinkan untuk bertempur melawan musuh secara langsung. Sementara orang yang berbadan lemah, kurus kering, kurang makan atau kurang gizi, tidak diberi izin untuk ikut berjihad. Karenan bagaimana akan bisa menjatuhkan lawan, sementara badan berpenyakitan, tidak mampu berdiri sendiri.
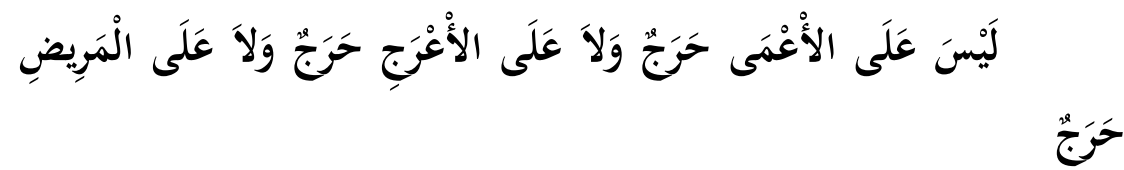

Terjemahnya:

"Tiada dosa atas orang-orang yang buta dan atas orang yang pincang dan atas orang yang sakit. Dan barangsiapa yang taat kepada Allah dan Rasul-Nya; niscaya Allah akan memasukkannya ke dalam surga yang mengalir di bawahnya sungai-sungai dan barang siapa yang berpaling niscaya akan diazab-Nya dengan azab yang pedih." (QS. Al-Fath : 17)

\section{E. Kesimpulan}

Dari penjelasan singkat dalam tulisan ini, penulis mengambil beberapa kesimpulan:

Jihad selain bermakna berjuang juga bermakna kesungguhan dan upaya terakhir, sebagaimana dalam firman Allah: "Dan mereka bersumpah dengan nama Allah dengan segala

21 Acheh Cyber Military. 2017. Syarat-Syarat Untuk Mengikuti Jihad Fisabilillah. Diakses 3 Januari 2017. http://achehcybermilitary.org/syarat-syaratuntuk-mengikuti-jihad-fisabilillah. 
kesungguhan." (QS. Al An'am: 109). Makna kata al jahdu menurut kamus Lisanul Arab yang ditulis oleh Ibnu Mandzur adalah melawan musuh, pengerahan segenap kemampuan manusia untuk mendapatkan yang diinginkan atau menolak yang dibenci.

Bahwa orang mengartikan jihad fi sabilillah adalah hanya sebatas berperang, maka sebenarnya tidak salah. Namun jihad fi sabilillah tidak hanya pada sebatas berperang melawan kaum musyrik yang mengganggu atau menzhalimi orang Islam saja. Melawan hawa nafsu dan melawan syaitan-pun masuk dalam kategori jihad fi sabilillah.

Bahwa jihad fi sabilillah adalah jalan Allah yang diberikan kepada kaum muslim untuk berjalan diatasnya, namun dalam pengamalannya hendaknya melihat dan mengkaji kembali beberapa syarat yang wajib untuk dipenuhi. Demikian hal-nya yang harus saudara-saudara muslim ketahui terkait keberangkatan ke Palestina.

Sangaji Jurnal Pemikiran Syariah dan Hukum 


\section{Daftar Pustaka}

Agha, Mahir Ahmad. 2005. Yahudi: Catatan Hitam Sejarah, terj. Yadi Indrayadi. Jakarta Timur: Qisthi Press.

A. Muchsin, Misri. 2015. Palestina dan Israel: Sejarah, Konflik dan Masa Depan. Jurnal MIQOT Vol. XXXIX No. 2 JuliDesember 2015.

Dewi, Ita Mutiara, Ajat Sudrajat dan Miftahuddin. 2008. Gerakan Rakyat Palestina: Dari Deklarasi Negara Israel Sampai Terbentuknya Negara Palestina. Tidak diterbitkan. Fakultas Ilmu Sosial dan Ekonomi, Universitas Negeri Yogyakarta.

Chirzin, Muhammad. 2006. Reaktualisasi Jihad fì Sabîl al-Lâh dalam Konteks Kekinian dan Keindonesiaan. Jurnal Ulumuna, Volume X Nomor 1 Januari-Juni 2006.

Abd al Baqi, Muhammad Fu'ad. 1991. Al Mu'jam al Mufahras li Alfazh al Qur'an al Karim (Kairo: Dar al Hadits.

Mandzur, Ibnu. Lisan al Arab al Muhit Juz I. Beirut: Dar Lisan al Arab.

Munawwir, Ahmad Warson. 1984. Al Munawwir: Kamus Arab Indonesia. Yogyakarta: Pondok Pesantren al Munawwir.

Handoko, Agus. 2014. Konsep Jihad Dalam Perspektif Alquran (Studi Tematik Dalam Tafsir al-Kasysyaf Atas Ayat-Ayat Jihad). Mizan: Jurnal Ilmu Syariah. Volume 2 No. 2 Desember 2014.

Asmara, Musda. 2016. Reinterpretasi Makna Jihad dan Teroris. Al Istinbath: Jurnal Hukum Islam STAIN Curup-Bengkulu Volume 1 Nomor 12016.

Jalal, Abdul dan Abdul Aziz. 2017. Pondok Pesantren Dan Jihad: Studi Tentang Pembelajaran Konsep Jihad Di Pondok Pesantren Nurussalam Ciamis. Jurnal Penelitian Pendidikan Islam. Volume 5 Nomor 12017.

Santosa, Imam. 2008. Nasihat Untuk Qiyadah dan Kader Dakwah. Jakarta: Robbani Press. 
Pramono, Slamet dan Saifullah. 2015. Pandangan Hamka Tentang Konsep Jihad Dalam Tafsir Al-Azhar. Dialogia, Jurnal Studi Islam dan Sosial Volume 13 Nomor 2015.

M. Sunusi, Dzulqarnain. 2011. Antara Jihad dan Terorisme. Makassar: Pustaka As-Sunnah.

Qardhawi. 2010. Fiqih al Jihad, Terj. Irfan Maulana, dkk. Bandung: PT. Mizan Pustaka.

Military, Acheh Cyber. 2017. Syarat-Syarat Untuk Mengikuti Jihad Fisabilillah. Diakses 3 Januari 2017. http://achehcybermilitary.org/syarat-syarat-untukmengikuti-jihad-fisabilillah.

Tuasikal, Muhammad Abduh. 2011. Dua Syarat Pergi Jihad. Diakses 21 januari 2011. https://rumaysho.com/1528-dua-syaratpergi-jihad.html

Wikipedia Indonesia. 2020. Negara Palestina. Diakses 25 Juli 2020. https://id.wikipedia.org/wiki/Negara_Palestina

Haryono, Willy. 2020. Erdogan Bertekad Lindungi Palestina dari Pencaplokan Israel. Diakses 26 Mei 2020. https://www.medcom.id/internasional/eropaamerika/ZkeBZp8K-erdogan-bertekad-lindungi-palestinadari-pencaplokan-israel.

Mahbub Ridhoo Maulaa. 2020. Usai Marah pada Uni Emirat Arab yang Dukung Israel, Presiden Erdogan Ancam dan Sebut Yunani 'Preman'. Diakses 16 Agustus 2020. https://www.pikiranrakyat.com/internasional/pr-01670866/usai-marah-pada-uniemirat-arab-yang-dukung-israel-presiden-erdogan-ancamdan-sebut-yunani-preman.

Sangaji Jurnal Pemikiran Syariah dan Hukum 